\title{
The role and importance of club cells (Clara cells) in the pathogenesis of some respiratory diseases
}

\author{
Wojciech Rokicki, Marek Rokicki, Jacek Wojtacha, Agata Dżeljijli \\ Department of Thoracic Surgery, School of Medicine with the Division of Dentistry in Zabrze, \\ Medical University of Silesia in Katowice, Poland
}

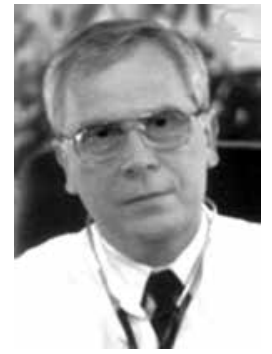

Kardiochirurgia i Torakochirurgia Polska 2016; 13 (1): 26-30

\begin{abstract}
The report presents the cellular structure of the respiratory system as well as the history of club cells (Clara cells), their ultrastructure, and location in the airways and human organs. The authors discuss the biochemical structure of proteins secreted by these cells and their importance for the integrity and regeneration of the airway epithelium. Their role as progenitor cells for the airway epithelium and their involvement in the biotransformation of toxic xenobiotics introduced into the lungs during breathing is emphasized.

This is followed by a discussion of the clinical aspects associated with club cells, demonstrating that tracking the serum concentration of club cell-secreted proteins is helpful in the diagnosis of a number of lung tissue diseases. Finally, suggestions are provided regarding the possible use of proteins secreted by club cells in the treatment of serious respiratory conditions. Key words: club cells, Clara cells, xenobiotic detoxification, progenitor cells.
\end{abstract}

The respiratory system of mammals is comprised of two anatomical parts: the conducting zone that transports the air to the lungs and the respiratory zone responsible for gas exchange. The conducting zone includes the trachea, bronchi (main, lobar, segmental), and bronchioles.

The respiratory zone is the lung parenchyma proper, which consists of the respiratory bronchioles, alveolar ducts, and pulmonary alveoli. Respiratory bronchioles form the margin between the conducting and respiratory zones. Biologically, each of the three regions is constructed of different epithelial cells which have various physiological functions.

The epithelium lining the primary airways includes the following types of cells:

- ciliated cells with approximately 250 cilia on the apical surface,

- goblet (or beaker) cells which produce and secrete mucus,

- brush cells with numerous microvilli on the surface,

\section{Streszczenie}

W pracy omówiono komórkową budowę układu oddechowego wraz z historią odkryć komórek oskrzelikowych zwanych komórkami Clary. Przedstawiono ich rozmieszczenie w drogach oddechowych i narządach człowieka. W dalszej kolejności scharakteryzowano ultrastrukturę komórek Clary. Omówiono budowę biochemiczną i znaczenie białek wydzielanych przez te komórki dla integralności i odnowy nabłonka dróg oddechowych. Podkreślono ich rolę jako komórek progenitorowych dla nabłonka dróg oddechowych, a także udział w biotransformacji wprowadzanych do płuc z powietrzem oddechowym toksycznych ksenobiotyków. W drugiej części pracy przedstawiono aspekty kliniczne związane z komórkami Clary, wykazując, że śledzenie surowiczego stężenia białek przez nie wydzielanych jest pomocne w diagnostyce szeregu schorzeń tkanki płucnej. Na koniec wysunięto sugestie o możliwym zastosowaniu białek wydzielanych przez komórki Clary w leczeniu poważnych schorzeń układu oddechowego. Słowa kluczowe: komórki maczugowate, komórki Clary, detoksykacja ksenobiotyków, komórki progenitorowe.

- undifferentiated basal cells with high mitotic potential,

- small granule cells belonging to the group of APUD cells which regulate the secretory function of goblet cells and glands in the mucous membrane.

In the respiratory bronchioles, forming the margin between the conducting and respiratory zones, the following types of cells can be distinguished:

- ciliated cells (the most common),

- microvillar cells (few),

- small granule cells (few),

- bronchiolar cells known as club cells or Clara cells (CCs).

In the pulmonary alveolar epithelium, the following cell types can be distinguished:

- type I pneumocytes,

- type II pneumocytes,

- type III pneumocytes (rare),

- numerous pulmonary macrophages [1]. 
Bronchiolar cells were first described in 1881 by Rudolph Albert von Kölliker, a Swiss physician, anatomist, and physiologist, but his discovery was forgotten for decades. As late as in 1937, the Austrian anatomic pathologist, Max Clara described a specific type of cells present in the bronchial epithelium; the cells were initially called Clara cells, but are now known as club cells (CCs) or bronchiolar exocrine cells.

Max Clara was an ardent Nazi supporter and joined NSDAP (Nationalsozialistische Deutsche Arbeitpartei) in 1935; the results of his studies were based on the examination of lung samples acquired from prisoners murdered in concentration camps around Dresden. After the end of World War II in 1945, he became a persona non grata in German scientific circles. In 1950, he left Germany for Turkey, where he became a professor at the University of Istanbul [2].

Club cells (CCS) are cubical in shape, and their surface facing the bronchiolar lumen is bulging; they do not have cilia or secrete mucus, which is why they are also known as bronchiolar cells or non-ciliated non-mucous secretory cells of the bronchiolar epithelium [3]. Examination with an electron microscope reveals the smooth and rough endoplasmic reticulum located primarily in the apical part of the cell. A large number of mitochondria is present, also located mostly in the apical part of the cell. The significant number of these organelles attests to the high level of their metabolic activity. Each cell also contains approximately 6 dense membrane-coated granularities, approx. $0.3 \mu \mathrm{m}$ in size, located primarily near the basement membrane. Chemically, the granularities are proteins, glycoproteins, and lipids. The Golgi apparatus is well developed. The centrally located cell nucleus forms approx. $30 \%$ of the cell; it is very wrinkled and contains many nucleoli. The apical part of the cytoplasm contains small amounts of secretory granularities. Additionally, CCs contain substantial amounts of cytochrome P-450 working jointly with mixed-function oxidases. CCs produce and secrete a number of substances in both an apocrine and a merocrine manner $[3,4]$. The secretory activity of CCs is stimulated by adrenergic fibers [5].

In physiological conditions, CCs constitute approximately $9 \%$ of the total population of airway epithelial cells in human lungs; in terms of distribution, they are practically absent in the mucous membrane of the proximal segments of the bronchial tree (the trachea and the primary, lobar, and segmental bronchi). Approximately $11-22 \%$ of CCs are located in the terminal bronchioles. In physiological conditions, they constitute approximately $15-44 \%$ of all proliferating cells in this part of the lungs [6].

Apart from lungs, in the human body, CCs are also present in the gravid uterus, kidneys, and prostate $[7,8]$.

The primary secretory product of CCs is uteroglobin/ blastokinin; its composition is the same as that of the protein secreted by gravid endometrium, hence the name uteroglobin. In scientific literature, the protein is known by many names including: uteroglobin, club cell secretory protein (CCSP), club cell protein 16 (CC16), club cell protein 10 (CC10), secretoglobin (SCGB), human protein 1 , and urine protein 1.
Human protein CC16 (mass: $15.8 \mathrm{kDa}$ ) secreted by CCS is a homodimer without sugar residues; each unit is composed of 70 amino acid residues bound with covalent bonds. Its structure includes a hydrophobic pocket for binding lipophobic ligands, such as e.g., biphenols. It is resistant to the action of proteases, low temperature, and $\mathrm{pH}$ changes. It has also been demonstrated that, due to its relatively low molecular mass, the protein is catabolized in renal distal tubules [9]. In humans, the gene encoding CCSP has 3 short exons and 2 introns (4.1 kb in length). Its genes are located on chromosome 11q12.3-13.1 in the vicinity of other genes associated with inflammatory and immune processes [10, 11].

Apart from this protein, CCs also secrete many essential substances, including the KL-6 protein and a number of glycoproteins, lipids, and proteins providing chemical and physical protection for both pulmonary surfactant and small airways.

The protective role of protein CC16 has been demonstrated in experimental studies on mice. According to the observations, its deficiency is associated with increased susceptibility of lungs to viral infections and oxidative stress. Labeling the serum concentration of CC16 has been employed to demonstrate CC damage in various acute and chronic lung diseases [12].

Additionally, it has been shown that the protein's expression is significantly enhanced by some transcription factors stimulated by cytokines, particularly by interferon gamma. In turn, in neoplastic cells of the respiratory and urinary system, protein CC16 functions as an antagonist of the CC10/UG phenotype, creating two forms outside and inside the cellular regulator encompassing both inflammation and neoplastic transformation [9].

A study in 2014 demonstrated that, in preterm infants, an increase in the serum concentration of protein KL- 6 secreted by CCs to more than $79 \mu \mathrm{g} / \mathrm{ml}$ is a good indicator of advanced bronchopulmonary dysplasia, much more sensitive than the concentration of protein CC16 alone. The results prove that labeling the concentration of both these proteins concurrently results in a clear increase in their predictive value in diagnosing dysplasia [13].

Furthermore, it has been observed that the proinflammatory cytokine TNF- $\alpha$ very clearly induces the production and secretion of proteins by CCs, thus significantly modulating the inflammatory response in the airways [14].

Despite constantly conducted large-scale studies involving both physiological and pathological conditions, the role of CCs is still not fully understood. In physiological conditions, they are believed to have the following fundamental functions:

- they secrete the primary components of the extracellular substance lining the respiratory bronchioles,

- they are progenitor cells for both themselves and ciliated cells,

- they regulate the contents of secretion (fluid) in the distal segments of the respiratory tract,

- in the lungs, they play a key role in the biotransformation of inhaled xenobiotics together with cytochrome P-450 and mixed-function monooxygenases. 
Club cells participate in the biotransformation of many harmful and toxic compounds introduced to the lungs with inhaled air, including furan, hydrocarbons (including aromatic hydrocarbons), naphthalene and its derivatives, ozone, benzo[ $\alpha$ ]pyrene, elements of tobacco smoke, coumarins, nitric oxides, and many other substances too numerous to mention. Detoxification of the abovementioned compounds occurs with the participation of cytochrome P-450, monooxygenases, and flavin-containing monooxygenases. As early as during the first hour after exposure to these compounds, a number of structural changes occur in CCs, including nuclear chromatin margination and clumping, mitochondrial swelling, and dilation of the endoplasmic reticulum. After approximately 24 hours from exposure, CCs become enlarged, and a substantial number of vacuoles form near the cellular membranes [15]. For this reason, CCs are believed to play an important role in protecting the airways from the harmful influence of a toxic external environment [5]. Hence, a significant reduction in the number of CCs has been observed in the airway epithelium of chronic tobacco smokers (at least 10 pack-years) [16].

In 1967, J. Niden published a paper in Science, suggesting that CCs secrete pulmonary surfactant. This research was corrected in 1975 by Kuhn et al. who demonstrated that surfactant lipids are primarily produced in type II pneumocytes and not CCs. However, it turned out that CCs secrete three types of proteins (known as proteins $A, B$, and $D$ ) which bind the surfactant, stabilizing its structure and, thus, serving a protective function for the compound $[17,18]$.

The respiratory system of mammals, comprised of highly specialized cells, not only forms a physical barrier for the external environment, but also, under the influence of a number of unfavorable environmental factors, secretes various biologically active substances (inflammatory and anti-inflammatory factors, antibacterial peptides, immune system cells, etc.) that can repair even significant damage.

Airway epithelium is renewed, maintained, and repaired primarily by endogenous stem cells (progenitor cells). Many experimental studies conducted on both lung segments and tissue cultures of human respiratory epithelium have demonstrated unequivocally that CCs constitute one of the primary sources of stem cells. Their authors concluded that, in the lungs of newborns, CCs may differentiate to form both type I or II pneumocytes and ciliated cells [5, 19].

The signal for CC differentiation is provided by $\beta$-catenin, a cytoplasmic glycoproteid dependent on calcium ions, belonging to the family of cadherins, which, in turn, are responsible for the stabilization of intercellular connections and morphogenesis.

Experimental studies have demonstrated that soluble E-cadherin (mass: $80 \mathrm{kDa}$ ), a product of proteolytic breakdown of cadherin, stimulates the differentiation of CCs during regeneration and/or damage of bronchiolar epithelium [19-21].

It has been suggested that bronchiolar CCs may be tumorigenic and, under the influence of the mutation inducing KRAS gene (G-12 D), may start (induce) neoplastic processes in the lungs, leading to the development of adenocarcinoma [22].

In turn, other experimental studies have demonstrated that dysregulation of the signal of the catenin pathway results in the development of various lung pathologies; therefore, it is assumed that the origins of the signal that initiates tumorigenesis (or even carcinogenesis) in lung tissue may include CCs $[4,5,23]$. However, the mechanism of progenitor CC differentiation remains largely unknown.

The clinical aspects associated with CCs are not fully understood. However, it is believed that progenitor CCS participating in the repair of airway epithelial damage constitute causative factors behind the development of the nosological entities listed below (probably by stimulating the development of mesenchymal fibroblasts):

- mucoviscidosis (cystic fibrosis),

- ARDS,

- COPD,

- pulmonary fibrosis,

- pulmonary emphysema,

- pulmonary hypertension,

- subglottic tracheal stenosis,

- tracheomalacia [24].

Bronchiolar CCs are believed to play a key role in the regulation of pulmonary homeostasis and inflammatory conditions (both acute and chronic). They serve the function of progenitor cells, participate in xenobiotic metabolism, and regulate the pulmonary immune system. They are destroyed as early as 24 hours after the action of a harmful factor and are rebuilt after approximately 30 days [25].

As previously demonstrated, CCs secrete various proteins into the bronchial tree, blood, and urine; labeling these proteins has found its application in the diagnosis of some conditions. Their concentration has been observed to increase in both pulmonary fluid and blood serum of patients with sarcoidosis or pulmonary fibrosis and in patients undergoing mechanical ventilation with high positive end-expiratory pressure (PEEP) values. The authors of this report suggested that the concentration of the CC16 protein is a good non-invasive indicator for the assessment of the respiratory system's integrity $[12,26]$.

These observations were confirmed by Wutzler et al. in 2012; according to their report on patients with multiple injuries, the serum concentration of protein CC16 would rapidly rise immediately after the injury, decrease within the first 24 hours, and again increase systematically from the $2^{\text {nd }}$ day forward. The authors concluded that the protein is a good indicator of secondary pulmonary insufficiency in patients with multiple injuries [27]. Elevated concentration of the CC16 protein in bronchiolar secretion is considered to be a good marker of increased lung-blood barrier permeability [12].

Still other authors have demonstrated that the serum concentration of the CC16 protein and surfactant is a useful marker for detecting the early form of silicosis [13]. Labeling this protein in blood and urine as a good marker for fibrotic changes in pneumoconiosis patients has also been proposed [28]. 
In turn, a large-scale study conducted on approximately 1000 patients with advanced lung cancer demonstrated that the serum concentration of the CC16 protein can be used to predict a mortality risk [29].

For many years now, the proteins secreted by CCs have been the subject of searching molecular and clinical studies. The reasons behind this interest include their anti-inflammatory and immunomodulatory properties; furthermore, studies on cell lines of human pulmonary adenocarcinoma have suggested that they also possess antineoplastic properties. Although the mechanism of this phenomenon has not yet been fully elucidated, it has been suggested that protein CC10-CC16 is "a good candidate" for experimental lung cancer immunotherapy [30].

It is to be hoped that further studies on CCs and their secretory proteins will give rise to their application in therapy for many lung conditions.

\section{Disclosure}

Authors report no conflict of interest.

\section{References}

1. Ostrowski K. Histologia. PZWL, Warszawa 1988; 528-542.

2. Kaiser S. Tradition on charge? Sources of body procurement for the Anatomical Institute of the University of Cologne in the Third Reich. J Anat 2013; 223: 410-418.

3. Singh G, Katyal SL. Clara cell proteins. Ann N Y Acad Sci 2000; 923: 43-58.

4. Aryal G, Kimula Y, Koike M. Ultrastructure of Clara cell stimulated by isoproterenol. J Med Dent Sci 2003; 50: 195-202.

5. Reynolds SD, Malkinson AM. Clara cell: progenitor for the bronchiolar epithelium. Int J Biochem Cell Biol 2010; 42: 1-4.

6. Boers JE, Ambergen AV, Thunnissen FB. Number and proliferation of clara cells in normal human airway epithelium. Am J Respir Crit Care Med 1999; 159: 1585-1591.

7. Burmeister R, Boe IM, Nykjaer A, Jacobsen C, Moestrup SK, Verroust P. A two-receptor pathway for catabolism of Clara cell secretory protein in the kidney. J Biol Chem 2001; 276: 13295-13301.

8. Hong KU, Reynolds SD, Giangreco A, Hurley CM, Stripp BR. Clara cell secretory protein-expressing cells of the airway neuroepithelial body microenvironment include a label-retaining subset and are critical for epithelial renewal after progenitor cell depletion. Am J Respir Cell Mol Biol 2001; 24: 671-681.

9. Shijubo N, Kawabata I, Sato N, Itoh Y. Clinical aspects of clara cell $10 \mathrm{kDa}$ protein/uteroglobin (secretoglobin 1A1). Curr Pharm Des 2003; 9: 1139-1149.

10. Cöte O, Lillie BN, Hayes MA, Clark ME, van den Bosch L, Katavalos P, Viel L, Bienzle D. Multiple secretoglobin 1A1 genes are differentially expressed in horses. BMC Genomics 2012; 19: 72-78.

11. Firth AL, Dargitz CT, Qualls SJ, Menon T, Wright R, Singer O, Gage FM, Khanua A, Verma JM. Generation of multiciliated cells in functional airway epithelia from human pluripotent stem cells. Proc Natl Acad Sci 2014; 111: E1723-E1730.

12. Broeckaert FB, Bernard A. Clara cell secretory protein (CC16) characteristics and prospectives lung peripheral biomarker. Clin Exp Allergy 2000; 30: 469-475.

13. Wang SX, Liu P, Wei MT, Hevi L, Guo Y, Wang RY, Tu ZG, Liang XC. Roles of serum clara cell protein 16 and surfactant protein-D in the early diagnosis and progression of silicosis. J Occup Environ Med 2007; 49: 834-839.

14. Pilon AL. Rationale for the development of recombinant human CC10 as therapeutic for inflammatory and fibrotic disease. Ann NY Acad Sci 2000; 923: 280-299.

15. Blundell P. The biology of Clara cells - review paper. Int J Molec Med Adv Sci 2006; 2: 307-311.

16. Nomori H, Kobayashi R, Iga R, Fuyuno G, Morinaga S, Torikata C. Clinicopathological examination of the relation between Clara cells and smoking. Kyabu Geka 1994; 47: 888-911.

17. Nicken $\mathrm{AH}$. Bronchiolar and lavage alveolar cell in pulmonary phospholipid metabolism. Science 1967; 158: 1323-1324.
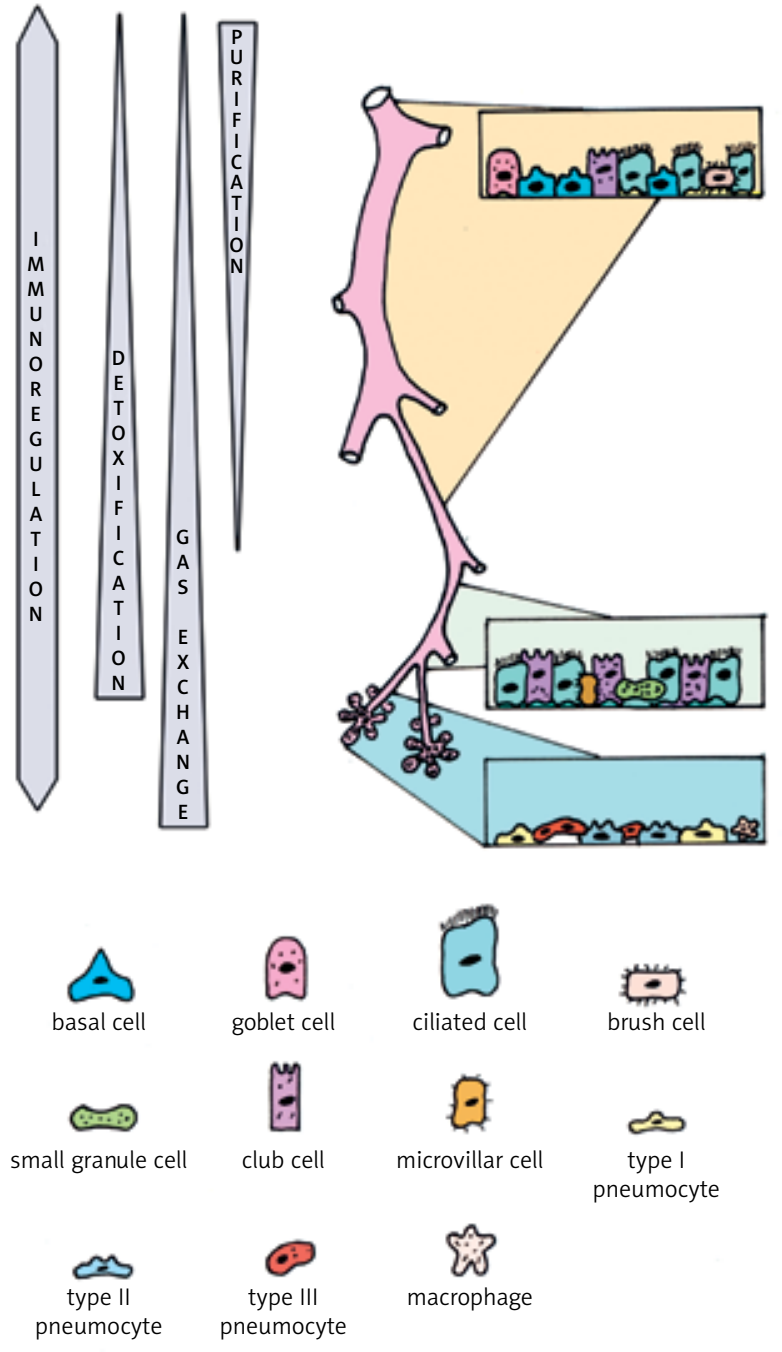

Fig. 1. Regional differences in the cellular composition and function of pulmonary epithelium

18. Kuhn C, Callaway LAS, Askin FB. The formation of granulesin the bronchiolar Clara cells of rats. II. Enzyme cytochemistry. J Ultrastruc Res 1975; 53: 66-76.

19. Xing Y, Li C, Sridurongrit S, Tiozzo C, Bellusci S, Borok Z, Kaartinen V, Minoo P. Signaling via Alk5 controls the ontogeny of lung Clara cells. Development 2010; 137: 825-833.

20. Ceteci F, Ceteci S, Zanucco E, Thacur C, El-Nikhely N, Fink L, Seeger W, Savai R, Rappo UR. E-cadherin controls bronchiolar progenitor cells and oncet of preneoplastic lesions in mice. Neoplasia 2012; 14: 1164-1177.

21. Smith MK, Koch PJ, Reynolds SD. Direct and indirect roles for $\beta$-catenin in facultative basal progenitor cell differentiation. Am J Physiol Lung Cell Moll Physiol 2012; 302: 580-594.

22. Cho HC, Lai CY, Shao LE, Yu J. Identification of tumorigenic cells in Kras (G12D)-induced lung adenocarcinoma. Canc Res 2011; 71: 7250-7258.

23. Kycko A, Reichert M. Current views on the mechanism of oncogenic transformation in pvine pulmonary adenocarcinoma. Post Hig Med Dosw 2007; 61: 797-804.

24. Weiss DJ. Concise review:current status of stem cells and regenerative medicine in lung biology and diseases. Stem Cells 2014; 32: 16-25.

25. Roth FD, Quintar AA, Lleimgruber C, Garcia L, Uribe-Echevarria EM, Malidonado CA. Restoration of the normal Clara cell phenotype after chronic allergic inflammation. Int J Exp Pathol 2013; 94: 399-411.

26. Kropski JA, Fremont RD, Calfee CS, Ware LB. Clara cell protein (CC16), a marker of lung epithelial injury, is decreased in plasma and pulmonary edema fluid from patients with acute lung injury. Chest 2009; 135: 1440-1447. 
27. Wutzler S, Backhaus L, Henrich D, Geiger E, Barker J, Marzi I, Lauer H. Clara cell protein 16: a biomarker for detecting secondary respiratory complications in patients with multiple injuries. J Trauma Acute Care Surg 2012; 73: 838-842.

28. Kotani K, Kawabata I, Mu H, Kurozawa Y, Itoh Y. Urinary protein $1 /$ Clara cell 16 concentrations and lung functions in male subjects with pneumoconiosis. Ann Clin Biochem 2007; 44: 560-562.
29. Guerrara S, Vasquez MM, Spangeriberg A, Halonen M, Martinez MD. Serum concentrations of club secretory protein (Clara) and cancer mortality in adults: a population-based prospective cohort study. Lancet Respir Med 2013; 1: 779-785.

30. Yoon JM, Lee KH, Lee SM, Lim JJ, Yang SC, Yoo CG, Lee CT, Han SK, Shim YS, Kim YW. The immune modulatory of Clara cell-10 in human peripheral monocytes and dendric cells. Int J Mol Med 2010; 26: 415-423. 